\title{
The Future of Journalism
} as a System, Profession and Culture:
The Perception of Journalism Students

\author{
Ana Milojević ** \\ Aleksandra Krstić \\ Aleksandra Ugrinić ${ }^{* * * * *}$
}

\section{SUMMARY}

Currently, there is clear need for traditional journalism to redefine itself. The intention of this article is to portray the voices of future journalists in this quest. Therefore, Belgrade University journalism students were assigned to write down their contemplations about the journalism of tomorrow in essayistic form. In order to systematize their narratives, three theoretical understandings of journalism are introduced based on a literature review: journalism as a societal system, profession and culture. The essays were analyzed using quantitative and qualitative content and critical discourse analyses. The students' anticipated changes in journalism understood as a system, profession and culture are discussed, with a special focus on language, in order to deconstruct how students evaluate the future of journalism. Furthermore, the article shows how students perceive their role in redefining journalism.

Key words: journalism studies, journalism, students, critical discourse analysis, future of journalism

\footnotetext{
* The earlier version of the study was presented at the $8^{\text {th }}$ CEECOM "Digital Media, Communication, Media, Communication Technology and Social Media practices" conference in Zagreb, 14-16 June 2015.

** Ana Milojević, Ph.D., Faculty of Political Sciences, University of Belgrade, Serbia, anamilojevic@gmail.com

${ }^{* * *}$ Aleksandra Krstić, Ph.D., Faculty of Political Sciences, University of Belgrade, Serbia, aleksandra.krstic@fpn.bg.ac.rs

**** Aleksandra Ugrinić, M.A., Faculty of Political Sciences, University of Belgrade, Serbia, aleksandra.ugrinic@fpn.bg.ac.rs
} 
Medij. istraž. (god. 22, br. 2) 2016. (83-105)

\section{Introduction}

The field of journalism is going through tremendous changes, which are attributable to global economic and technological factors. Academics, experts, media owners, journalists and citizens are expressing concern about the future of journalism as we know it. The main aim of this article is to include the voices of future journalists in the discussion about the uncertainties facing journalism. Since these future journalists are social actors who will shape the journalism of tomorrow, it is important to explore their attitudes and projections in order to anticipate possible trends in journalism and the durability of different legacies in journalism.

Tomorrow's journalists have often been the subject of academic research, and since the 1970s, substantial research has been conducted on the national scope of their attitudes. Lately, the amount of comparative work in this area has seen an increase (for example, Mellado et al., 2013; Nygren et al., 2010), but most of the research is quantitative and survey-based and mainly focuses on students' vocational motivations, their perceptions of the role of journalism, the ideals of journalism, students' views on ethical and professional standards, and the influence of education on journalism cultures. Students have rarely been asked about their thoughts on the future of journalism or been presented with the opportunity to express their opinion in an unstructured way. The study of Blaagaard (2013) is an exception, as it uses focus group interviews to incorporate the voices of students of international journalism into the discussion about citizen journalism. We have also opted for a qualitative research design, by asking students to write about their perception of the reinvention of journalism in an essayistic form. By using a combination of quantitative and qualitative content with critical discourse analysis of the students' essays, this article aims to answer the main research question, which is 'How do journalism students perceive the future of journalism?'

In order to deconstruct and systematize the students' discourses, we have started with the same question that has guided many scholars: 'What is (legacy) journalism?' (Deuze, 2005; Hartley, 1999; McNair, 2005; Russial et al., 2015). As Deuze (2004: 276) notes, journalism can be observed as 'a profession, as a social system, or as a certain set of practices and skills enacted by the particular group of "news workers" in the context of media organizations'. There is a multitude of such perspectives on the field of journalism studies, which is relatively young, interdisciplinary and cross-fertilized with theories, mostly of the middle range, with the scholars coming from different social sciences and humanities backgrounds (Löffelholz \& Quandt, 2005; Steensen \& Ahva, 2015; Zelizer, 2004). The last two decades have been marked by such efforts to solidify and demarcate the field of journalism studies. As a result, significant overviews of conceptual approaches with a national or language-speaking scope have emerged. Some of the key contributors have been 
The Future of Journalism as a System, Profession and Culture: The Perception...

Zelizer (2004) and Schudson (2003) for the USA and McNair (2003) for Great Britain; moreover, Löffelholz and Quandt (2005) have developed a synopsis of theoretical perspectives in Germany and Austria. Other scholars have had a chronological focus: for example, Domingo (2008) has summarized the development of online journalism research in three waves - normative, empirical and constructivist. On the other hand, Wahl-Jorgensen and Hanitzsch (2009) present a broader view, by identifying four distinct, but overlapping and co-existing phases, in the history of journalism research: normative, empirical, sociological, and global comparative.

In an attempt to synthesize the different theoretical approaches, this article offers three understandings of journalism: as a societal system, as a profession, and as a culture. This matrix was not developed to offer an all-encompassing generalization of the diversified theoretical observations about journalism, but to make sense of the future journalists' narratives about their vocation. However, we believe that it correlates strongly with the main theoretical perspectives and research strands in journalism studies, and can serve as a basis for more meta-theoretical discussions in the field.

\section{Theoretical framework: Three understandings of journalism}

\section{Journalism as a system}

Journalism can be perceived as a specific societal system or a subsystem functioning in a larger system. Some German authors have used the theoretical perspective of a system in studying journalism quite often (Görke \& Scholl, 2006; Loosen, 2015; Luhmann, 1996; Weischenberg, Malik \& Scholl, 2012). From their point of view, journalism enables society to observe itself by providing it with fact-based, relevant and up-to-date information (Görke \& Scholl, 2006; Loosen, 2015; Weischenberg, Malik \& Scholl, 2012). As Loosen (2015: 72) argues, 'the point of departure of every systems theoretical analysis is the difference between the system and its environment and drawing lines of demarcation is its basic operation'. Although relatively confined, societal systems are not isolated and self-sufficient, but rather, they are interrelated and interdependent. According to Görke and Scholl (2006: 648), 'systems are closed in the sense that they operate autonomously: they constitute their identity on the basis of system-specific operations', while at the same time, 'every system needs stimulations or irritations from outside the system, although these external stimuli cannot determine the operations of and within the system'. Therefore, the autonomy of a system is an important line of investigation, which in the case of journalism comes down to its structural and functional couplings with other societal systems - especially political and economic. Whether journalism is capable of guarding its performance from environmental impacts and influences has been a rather important and enduring question in journalism studies. 
Medij. istraž. (god. 22, br. 2) 2016. (83-105)

Scholars have been emphasizing on the huge influence of the economic realm on journalism since its beginning, but critique of its commercialization has been on the increase since the 1980s. According to McManus (1994), news production is governed by the interests of advertisers, investors, sources, and media consumers, rather than journalistic norms. Similar argumentation has been raised by scholars of political-economic orientation such as Bagdikian and McChesney (Bagdikian, 2004; McChesney, 2003). However, Fengler and Ruß-Mohl (2008: 667) find the normative economic perspective to be insufficient with regard to explaining current phenomena such as 'pack reporting', 'horse-race journalism', 'the rising influence of PR' and 'spin doctors', and describe journalists 'as rational actors seeking to maximize materialistic and nonmaterialistic rewards (e.g. attention, reputation, and fringe benefits)'.

Journalism can be equally instrumentalized by political actors (Mancini, 2012), and the level of parallelism between news work and politics is one of the main factors for classifying media systems (Hallin \& Mancini, 2004; Merrill \& Nerone, 2002). This line of thinking is also closely interlinked with the high-modern, classical paradigm of journalism (Dahlgren 2009; Vobič, 2014), or the highly normative, hegemonic western model according to Nerone (2013). This model assumes that news organizations are the keepers of democracy, so journalism must retain its independence against those in power and maintain trustworthiness in order to act as the 'watchdog' of people's interests by providing expert accounts of important public affairs.

\section{Journalism as a profession}

Journalism can be understood as a profession, and this lens has been used rather often: for example, Steensen and Ahva (2015: 10) state that 'the perspective of sociology with a focus on professionalism seems to have a firm position in the field'. Further, Das (2007: 145) has approached this from three angles: (1) investigating whether journalism can be considered a profession, (2) examining how journalists deploy the notion of professionalism in their practice, and (3) determining on what grounds journalists claim its professionalism.

The first line of research, which leans on the so-called 'trait approach' to evaluate the acquired level of professionalism within journalism, has proven to be almost a dead end. Analyses of specific traits that constitute a profession have usually led to the conclusion that journalism can be considered as a 'quasi, pseudo or failed profession' (Schudson \& Anderson, 2008: 91), or that 'the conventional model of professionalism, does not fit into journalism' (Das, 2007: 145). Therefore, scholars have turned their attention towards the notion of professionalism inside media or- 
The Future of Journalism as a System, Profession and Culture: The Perception...

ganizations and underlined the 'dependency' of journalism from the commercial and owners' perspectives (Soloski, 1989). Even arguments against the professionalization of journalism have been raised, rooted in the differentiation between two discourses of professionalism - organizational and occupational. Evetts (2003) defines organizational professionalism as a discourse of control used by managers in work organizations, and occupational professionalism as that which is employed by practitioners and is based on shared education, work culture, occupational identity, and codes of ethics endorsed by professional associations. In the context of journalism, the managerial concept of professionalism often collides with the journalistic notion of professionalism and impedes the independence of practitioners (Örnebring, 2009). In other words, economic constraints are transferred from the macro to the mezzo level, and transform into organizational pressures on news work.

The third way of thinking about professionalism in journalism coincides with the broader sociological shift from a structural-functionalist to a Weberian study of professionalization, viewed as the 'professional project' by Larson (1977) and 'professional struggle' by Abott (1988). Examining how occupations gain professional status and authority turned out to be more productive lines of inquiry. In a review of the literature on the professional project, Örnebring (2013: 38) distinguishes three core elements of the professional project, or 'three domains where claims of legitimacy are made': expertise, duty and autonomy. Expertise refers to a cognitive dimension, namely, the technical and formal knowledge required for 'professional' conduct. In this domain, entrance into the profession can be controlled. Duty is related to society, because the purpose of a profession is not only income, but also other higher duties, such as public service in the case of journalism. This is also a normative dimension that aims to standardize professional practice by enacting codes of ethics. Finally, autonomy implies that professions should be self-governed or relatively independent from the market and the state. These three dimensions or domains of professionalism (expertise, duty, and autonomy) have been rather resilient and consistent despite the significant changes in journalistic work during the past few decades. Moreover, although professionalization can be a conflicting force in journalism, most journalists today consider themselves as professionals and would not argue against further professionalization.

\section{Journalism as a culture}

The third understanding of journalism strongly correlates with the cultural strand in journalism studies, although it could also be roughly associated with newsroom ethnographies (such as in Peterson \& Domingo, 2008; Tuchman, 1978). Anderson (2008) marks the work of Zelizer (1992) as a 'cultural turn' that has enriched journalism studies with the discursive approach. Zelizer (1992) introduced the view of 
journalists as members of an interpretive community united by a shared discourse and collective interpretations of key public events. Such an approach, according to Anderson (2008: 225), ignores the forms of power not grounded in narrative, namely, 'other factors that might contribute to the reality-shaping abilities of journalists: state power, questions of hegemony, concentrations of economic capital, ethnic and class-based exclusions, and legal decisions'. However, Zelizer underscores the discursive aspects of journalistic identity (stories, symbols, and self-descriptions) and sets the grounds for elaborating a cultural understanding of journalism.

Hanitzsch (2007) has provided probably the most comprehensive definition of journalism as a culture, and it has been implemented in comparative research on journalism all over the world. He starts with the notion that culture manifests itself in the form of ideas (values, attitudes and beliefs), practices and artefacts (cultural products), and defined 'journalism culture' as a 'particular set of ideas and practices by which journalists, consciously and unconsciously, legitimate their role in society and render their work meaningful for themselves and others' (Hanitzsch, 2007: 369). Drawing on this conceptualization, Hanitzsch $(2007,2011)$ distinguishes three essential constituents of journalism culture: institutional roles, epistemologies and ethical ideologies. These constituents are further divided into seven principal dimensions.

Hanitzsch (2007: 370) has tried to distinguish the concept of journalism culture from similar notions of ideology by arguing that professional ideologies are the crystallizations or articulations of professional culture, and that 'journalism culture is more than an ideology; it is the arena in which diverse professional ideologies struggle over the dominant interpretation of journalism's social function and identity'. However, Deuze (2004: 279) defines the set of discursively constructed ideal typical values by which journalists legitimize what they do as a 'shared occupational ideology among news workers which functions to self-legitimize their position in society'. Similarly, Koljonen (2013: 142) introduces the concept of professional ethos as 'the shared discursive resources which journalists think about and identify the core ideals of the profession and negotiate its permanence and change'. Based on these works, it could be argued that the concepts of 'journalism culture', 'professional ideology' and 'professional ethos of journalism' overlap in many ways, but that they all point towards an understanding of how journalists give meaning to their news work.

\section{Background and context}

Journalism and journalism education are context dependent and deeply bound to specific socio-historical circumstances, or rather, the political, economic and cultural realms of different societies. In that respect, journalism and journalism educa- 
The Future of Journalism as a System, Profession and Culture: The Perception...

tion in Serbia have a complex legacy, stemming from the country's communist past, authoritarian rule and democratic reformation. Therefore, we can roughly differentiate between three historical periods with specific journalism cultures and education, which have shaped the Serbian media landscape and the journalism of tomorrow.

The first period is Socialist Yugoslavia (1945-1991), during which a journalist was defined as a 'socio-political worker' who advocates for the 'working class by providing common truth' (Vobič, 2014:10). The role of journalism was considered subordinate to that of the communist party and state interests, while work was bureaucratized and professional autonomy was limited. Accordingly, journalism was taught only at the University of Belgrade, Faculty of Political Sciences (UB FPS), and the curriculum mostly focused on political ideas, especially Marxist tradition, political systems and so on, and only offered a few theoretical courses about communication and journalism.

The second period (1991-2000) started with the collapse of communism and the separation of the Yugoslav republics. It was shaped by authoritarian regime, civil war, a decade long economic isolation and NATO bombing. In this period, the role of journalism was strongly attached to nation building and nationalistic interests. The media market was as poor as the rest of the country, and commercial media had just started to appear. Journalism had the societal status of a low paid, instrumentalized and overworked profession. Education remained centralized at UB FPS and encapsulated in an economic and academic vacuum, with scarce resources to improve and renew the journalism curriculum.

Lagging behind the rest of post-communist Europe, the economically and culturally devastated society entered a period of democratic transformation in 2000. The media system started reforming and assuming a more liberal form, while strong 'media assistance projects' resulted in the redefinition of the journalism role as a high-modern or classical paradigm (Dahlgren 2009; Nerone 2013; Vobič, 2014). Along these lines, journalism education began to adapt to new market and societal conditions. Private universities started to flourish, offering more vocational training and practical journalism courses instead of theory and political science courses. Faced with growing competition, UB FPS opened their doors for experienced journalists and editors who are now lecturers and mentors to students. The practice of print, radio, TV and online journalism started both in classes and in faculty newsrooms, where students were given the opportunity to create their own newspapers, web portals, radio and TV programs. Today, journalism education in Serbia is in accordance with Bolognian standards in two private and three state universities. Despite this, the journalism curricula differ only slightly, and mainly focus on normative aspects, suffering from the same challenges as journalism education worldwide. 
The numerous challenges in journalism education in Serbia are strongly interconnected with the journalism practice in newsrooms. The context of Serbian journalism, media and society also plays a role in the journalism students' articulations, and shapes their discourses about journalism and its future.

The Serbian media system is considered as an unsustainable mixed media system which only minimally meets the objectives of free speech, professional journalism, plurality of news sources, business management and supporting institutions (IREX, 2013). Additional problems are the incomplete process of media privatization, lack of finances and underdeveloped media competition (Krstić, 2016). The market is overcrowded with numerous media outlets, whereas many newspapers, TV and radio stations depend on local government subsidies (Krstić, 2012; Milivojević et al., 2012). Although the media legal framework has been reformed in the course of several time cycles since 2002, competent regulatory bodies are barely managing to survive independent of external influences.

The crisis of journalism as a profession reflects the severe political and economic pressures influencing media independence (Media Center, 2003). The practice of 'curtailing editorial independence', which stems from the interplay between the business elite, political parties and other societal actors in many post-communist countries of the Central and Eastern Europe (Štětka, 2013, p. 18), has been also identified in Serbia. Local electronic media, for example, are often conditioned to make contracts with large companies to reduce advertising rates or to broadcast advertorials within regular news bulletins to be able to survive (Krstić, 2016). Moreover, the two national journalistic associations have not been able to improve the overall status of the profession or reduce media instrumentalization. The associations do not cooperate with each other, and therefore, lack the influence to protect journalists from various pressures.

Along the shifting route of journalistic culture in Serbia, during the last fifty years, journalists have transformed from 'socio-political workers' into independent professionals who maintain a watchdog role in society. However, the changes around understanding of journalism are yet to see light. For example, ethical standards exist within the Code of Conduct, but are often ignored. On one hand, tabloidization and profit orientation lead to violation of basic ethical standards. On the other hand, even journalists admit that they often do not recognize, apply or comply with the ethical norms of journalism (Milivojević et al., 2012: 61). Therefore, the crisis of journalistic culture is defined by loose professional standards and a crisis of ethics, which have created an ambience in which it is difficult to practice the watchdog role. 
The Future of Journalism as a System, Profession and Culture: The Perception...

\section{Method}

In line with the main aim of this research, journalism students of UB FPS were asked to write an essay about the journalism of tomorrow. UB FPS was selected for this study on several grounds. The journalism department was opened in 1968, while the rest of the universities have had journalism programs for less than a decade. Furthermore, several private faculties and journalism programs have been opened and closed in the past ten years. Compared to the other two state universities, UB enrols more students and offers more state scholarships, so it attracts the best pupils from all over the country. Students from the south of the country gravitate to the University of Niš, while those from the north, to the University of Novi Sad. UB FPS, with the highest rank in the country and the longest tradition, has the most important influence on the journalist workforce in Serbia. Based on this, it can be argued that Belgrade University students are good representatives of the upcoming population of journalists in Serbia.

Undergraduate students in their final year were chosen as research participants, since they are the closest to entering practice or have already been working as journalists. Furthermore, they already have good theoretical knowledge and at least some practice, either through internship or by working for student media at UB FPS. They were asked to write an essay during two connected classes (total time: hour and a half) as part of the Communication Theory course. Since the assignment was given in the introductory class, the curricula of the course had no significant influence on the students' narratives. The topic was explained on the spot, and students were given only practical instructions (length and organization of the essay) to minimize influence on their opinion. Moreover, the students were assured that the essays would not be graded for the course.

A total of 80 students, most of them female ( $80 \%$ ), completed the assignment. Twenty seven essays were discarded, because the argumentation was poor, the student had missed the topic, or the thoughts were unsubstantiated. Fifty-three essays that were between 500 and 800 words long were used for quantitative and qualitative content analysis, in combination with critical discourse analysis (CDA). Although quantitative and qualitative methods are usually used separately in research, strong arguments are also raised in favour of the mixed-methods approach (Brannen, 2005; Onwuegbuzie et al., 2009). Scholars even argue that CDA, being probably the most complicated qualitative method of textual analysis, can be fruitfully synergized with other linguistic methods (Baker et al., 2008). Since the main research question has been further divided into four elaborate questions, different methods were applied. Following Krippendorf's (1980) definition of content analysis, we have searched for the linguistic structures in the essays to answer the following questions: 
Medij. istraž. (god. 22, br. 2) 2016. (83-105)

RQ1. How do students' essays relate to the theoretical understandings of journalism?

Much like the field of journalism studies, the student essays were also boundless. Most often, the students leaned on different understandings of journalism in building the argument in the course of one essay. Therefore, a complete thought, or sentence, was defined as a unit of analysis. It allowed for the classification of the obtained data from students' essays and the quantification of references to journalism as a societal system, profession and culture. For example, references to professional domains, i.e. professional values, ethics, authority, autonomy, inter-organizational constrains, and the socio-economic status of journalism, were placed under the understanding of journalism as a profession. When students wrote about economic, political and other pressures endangering the independence of journalism in the society and media instrumentalization, we considered their narrative to refer to journalism as a societal system. References to the interpretation of news, perceptions of various roles and professional norms of journalism were used for the analysis of journalism as a culture. However, the quantitative treatment of data was not adequate to answer the following question:

RQ2. How do students evaluate different aspects of journalism within the three understandings: journalism as a system, profession and culture?

For answering RQ2, qualitative content analysis was considered as the most appropriate method for identifying the underlying themes in the textual material (Bryman, 2004). In order to anticipate the development of journalism, it is valuable to investigate what students aspire to achieve and which practices they condemn in journalism. Therefore, the underling themes about journalism as a system, profession and culture were identified, as well as the most important trends which students stressed as being negative or positive. Although students were explicitly asked to write about the future of journalism, their prognosis was based on actual trends. The present and future of journalism were equally discussed in most essays. Such essay structures affected the analysis. We therefore decided to differentiate between positive and negative evaluations of present and future journalism within the three understandings and to structure the results accordingly. As journalism students have also been considered as an important source of social power, we have also examined the following question:

RQ3. How do journalism students label the future of journalism?

In line with various aspects of their personal and group views on journalism, we have used CDA to answer RQ3. In contrast to other critical perspectives in communication studies, CDA allows for a 'general, structural and focused' examination 
The Future of Journalism as a System, Profession and Culture: The Perception...

of various groups in a society, as it not only deals with power relations between groups, but also provides an interpretive and explanatory approach and 'general insights, and sometimes indirect and long-term analyses of fundamental causes, conditions and consequences' of various issues (Van Dijk, 1993: 253). The labels used throughout the analyzed essays show that the content is not simply semantic. According to Van Dijk, statements become credible only if they have other persuasive moves embedded in the specific discourse (1993: 264). These moves are recognized in the students' discourse as: lexical style (words chosen to describe the negative evaluation of certain issues), rhetorical figures (euphemisms, metaphoric phrases, etc.), and argumentation (when the positive or negative evaluation follows the facts given in the description of the journalism as it is seen in the nowadays-future relation). Finally, students have been considered as important 'agents of change'. Therefore, we have examined the following question:

RQ4. How do students see their role in shaping the future of journalism?

These perceptions were coded at the level of the whole essay according to the following scale: 0 (do not see their role), 1 (see themselves as agents of change) and 2 (unable to influence the future). For example, essays referring to 'young generations', 'our generation', 'us', 'educated young people' or 'future journalists' were coded in relation to students' perceptions of their ability or inability to influence the future of the profession.

\section{Results: Mapping the understandings of journalism in students' narratives}

Quantitative content analysis data show that the number of units of analysis addressing journalism as a system and profession is only slightly lower than the units referring to journalism as a culture (see Figure 1).

An in-depth look reveals even higher correlations between students and academic narratives.

\section{Students' evaluation of journalism as a social system}

The first outlined discourse depicts the tensions between democratic ideals that journalism should serve and the prevailing practices. This discrepancy is ascribed to malfunctioning of the Serbian media system: 'in our country, journalistic standards do not supplement democracy' (essay 1). Yet, this discourse is at the same time positive towards the democracy-journalism nexus. Students believe that the function of journalism in society should stay the same: to investigate, provide facts and 


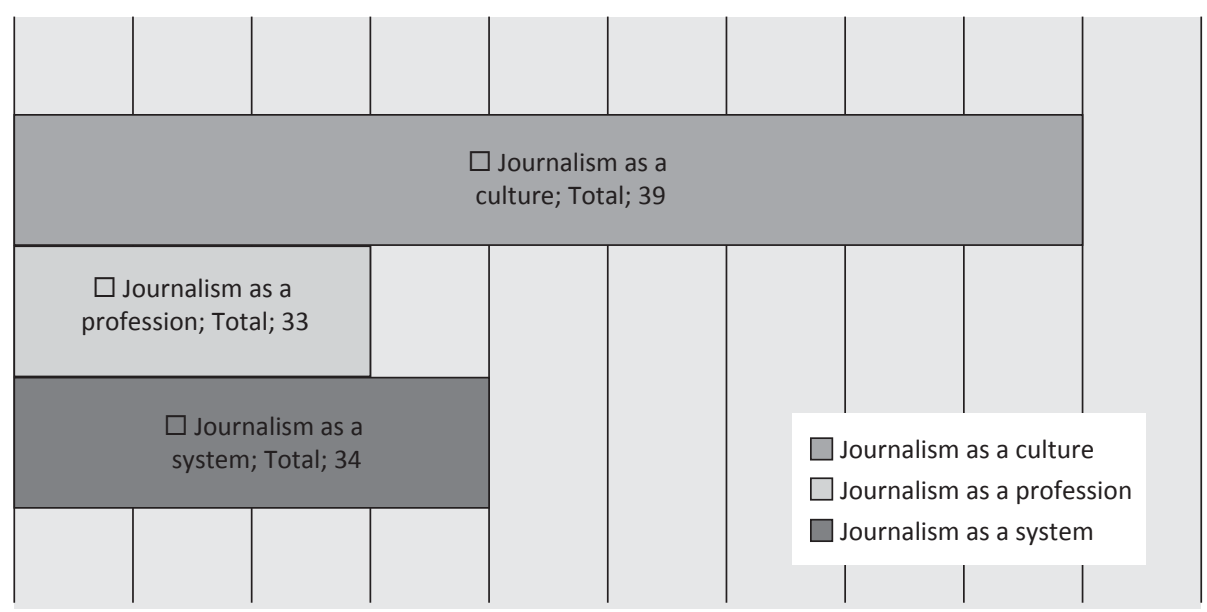

Figure 1. The number of student references to journalism as a culture, profession and societal system (counted by the number of complete thoughts or sentences)

Slika 1. ??? ???

ensure the running of democracy (essay 27). In this context, the students call upon the entire society to contribute to the 'rise of democratic values' (essay 2), in order to amend the democratic deficiency of journalism as a system.

In the second discourse, journalism was portrayed as largely dependable on profit, and journalists were seen as 'puppets on strings' (essay 5), pulled mostly by interest in profit. The students seem to be pessimistic, and believe that negative trends will expand further, that even the technological developments are not sufficient to secure the economic foundation of journalism. The students also echo scholarly accounts of political pressures on journalism. They emphasize that media are susceptible to the influences of various political actors. Journalists are blamed for having a shady relationship with those in power, acting as 'advertisers of the ruling elite' (essay 33), thus subordinating 'journalism to the needs of the political establishment' (essay 16), and creating the impression that 'media content has not been created by journalists, but politicians' (essay 49). Some students interpret political parallelism as a form of rapidly growing 'censorship' and see the Serbian media system as lagging behind contemporary processes of technological media development: 'while other countries try to improve television digitalization, we are still dealing with issues of media freedom discussed in the $19^{\text {th }}$ century' (essay 53). The evaluation of future developments is divided between 'pessimists' who predict the growth of self-cen- 
The Future of Journalism as a System, Profession and Culture: The Perception...

sorship, the diminishing of critical thinking and the maintenance of the status quo, and simplified optimistic views that the professional system which will eventually win over the restraints imposed by political actors.

\section{Students' evaluation of journalism as a profession}

The students have identified the same issues as scholars, and point to the need for journalism professionalization or completion of 'professional projects'. They have criticized the openness of the profession and stressed on the significance of journalistic education. A common argument among students is: 'If anyone can be a journalist, regardless of the education or knowledge, no one will be able to improve news reporting and empower the profession' (essay 15). They also note that the education system must be suitable for new generations of multitasking journalists and suggest the adoption of a 'mentoring approach' aimed at 'building practical journalistic skills' (essay 31 ).

The low economic and social status of journalists is identified as an immediate threat to professional practice. The fear of losing jobs, stressful working environment and miserable salaries has been identified as the main cause of the 'disturbed foundations' of journalism, which is 'showing the last signs of existence' (essay 38). The public image of journalists prone to 'influences', 'biased reporting' and 'spreading false information' is ascribed to weak solidarity between colleagues (essay 20). Overall, the students are of the opinion that the profession is in permanent crisis, and that journalists are degrading into 'storytellers for children' (essay 37). Such perspectives on the current state of journalism expand over the students' views of the future. Only a few believe that journalists will earn more if media managers employ less but more qualified journalists.

Professional and ethical standards are also considered as problematic. The students share the impression that journalists now 'follow cash' instead of 'professional standards' (essay 47), but believe that 'high ethical standards' must make the 'base for tomorrow' (essay 10). Besides those who believe in 'well educated journalists applying ethical principles', there are others who predict that the new media environment will lead to further erosion of professional standards.

The students perceived that professional integrity and autonomy were being violated. Media organizations are observed as an impediment to the profession: 'Media are like puppet theatre. Owners and editors are directing their puppets behind the curtain and if some puppet does not act according to scenario, they simply replace it' (essay 31). Therefore, a number of students have questioned the power of journalists to improve the profession within organizational constraints. However, several of the analyzed essays highlight journalism as a powerful profession, acknowl- 
Medij. istraž. (god. 22, br. 2) 2016. (83-105)

edging 'good' journalists who will contribute to overall empowerment, and referring to the 'unused societal potential' of young generations who will be able to 'wake the profession up from existing social inertia' (essay 39).

\section{Students' evaluation of journalism as a culture}

The students have evaluated the present state of journalism as a culture in a negative manner, by addressing the prevalence of tabloids, scandals and infotainment. They refer to this aspect of journalistic culture as a 'sick, tabloid state of affairs', 'idiotic sensations, spectacles and fabrications', 'yellow journalism', 'less quality', 'false, kitsch', and 'scandalous'. The students' disappointment also spreads into their future expectations. They see the entertaining role intensifying and turning into an 'unstoppable trend', in which the sensationalistic and tabloid media will flourish. Several quotes are illustrative of this: 'The entertaining role will prevail in the future, the audience will be over flooded with profit-oriented tabloids and content easy to read' (essay 22); 'the trend will be supported by lower educated parts of population' (essay 26); and 'it will be even harder to distinguish between hard and soft news, public and private life, because the audience will be drawn to participate in sensations' (essay 42). Along the lines of Hanitzsch's (2007) interventionism dimension, the informative and gate-keeping role of journalism has also been discussed. The students describe it as the basic, most important function of journalism, where news selection and fact checking are seen as cornerstones. The students highlight a clear distinction between professional and citizen journalists: 'Anyone can be a journalist online, but the information is often unchecked and false' (essay 28). In the narratives of the future, the informative and gate-keeping role is addressed in three different ways. Firstly, it is seen to guarantee the future of the profession and to remain the solid basis for everyday practice. Secondly, it is seen as becoming even more important, especially in the context of information abundance, where the need for information selection, editing, interpretation, framing and contextualizing has been addressed as necessary. Thirdly, a number of students expect automization of the gate-keeping role, where journalists are expected to become robots and aggregators of online data, rather than providers of information. The watchdog role is thus perceived as underdeveloped. Although the media have been emphasized as the 'eyes and ears of the public' (essay 10), they are blamed for not overseeing the government in Serbia.

The students have also addressed the interpretation of reality, or journalism epistemologies, especially empiricism (Hanitzch, 2007). The interpretive role is understood as storytelling and a more in-depth analysis of contemporary economic, societal and political events and problems. Students expect this role to become more 
The Future of Journalism as a System, Profession and Culture: The Perception...

significant with regard to preservation of the endangered profession: 'The interpretation will prevent journalism from disappearing' (essay 44). This understanding correlates with the students' overall demand for better quality journalism as the main counterpoint to its death.

\section{Label of the future of journalism}

Six key points that indicate the label of journalism in the future have been identified in the students' essays. They see the development of journalism within the information society, journalistic values, adaptation to changes, rebirth of the profession, the role of the audience and uncertainty.

When addressing the future of journalism within the information society, students tend to look into the niches of rapidly growing technology, where the profession is expected to naturally change. Words such as convergence, multitasking, multimedia, web TV, evolution, collaboration, etc., merge the narrative of the future with already existing forms of journalistic practices. On the other hand, a number of students believe that journalistic values will be the core of the future. The language used to describe the values is more complex. For example, positive attributes have been identified in phrases such as 'more valuable and more quality profession', 'good stories well told', 'courageous media and journalists', 'enthusiastic', and 'unbiased journalism'. The positive associations of journalistic values mostly correspond with individual strengths or the idealized collective identity of media workers. It can be argued that emotional appeal and personalization, expressed through the attributes 'courageous', 'enthusiastic', and 'unbiased', are in line with the already recognized watchdog, informative and interpretative journalistic roles. However, the values expressed here correlate more with the ethical, cultural and social values of democracy: freedom, justice, appreciation, confidence and integrity. Following the same discursive pattern, the students have negatively evaluated the future of journalism in metaphoric phrases such as 'the diggers of social garbage', 'puppets', 'Golden age of journalism will never rise', etc. Pessimistic labelling metaphors have been mostly used to address journalists, and not the values of the profession.

Interestingly, although discussed before, the adjustment to changes and the uncertainty of the future of journalism have not been explicitly labelled. The role of the audience and the 'rebirth' of journalism are mostly expressed in the noun phrases 'the big journalism', 'the loss of privacy', etc., rather than verb phrases that would explain the further development of journalism as an active process. The rebirth of journalism is seen as an idealized form of future development of a profession that has already died in the present. Yet, in order to revive it, only a 'grand' or 'big' form 
Medij. istraž. (god. 22, br. 2) 2016. (83-105)

of journalism will have to appear again. Therefore, students do not anticipate the rebirth of the profession in ordinary forms of appearance, but solely in the form of the 'grandiose' journalism that has existed throughout history. Further, those who perceive the audience to be the centre of the future of journalism emphasize on interactivity, engagement and citizens' input via social media.

\section{Discussion}

Students can be considered as important societal agents with the power to re-define, re-invent or steer the course of tomorrows' journalism. In 26 essays, the students identified themselves as agents of change, while in 21 essays, there was no reference to students' role in the future of journalism. Only six future journalists were sceptical about their ability to change anything, contrary to those who explicitly stated that they will 'give a contribution to the professional transformation and prevent journalism from digging its own grave' (essay 6). Currently, they seem devoted to the high modern paradigm of journalism and willing to indulge in the practice, with an ambition to solve the identified problems within all three understandings of journalism.

In the students' essays, journalism as a system has been addressed in line with political and economic pressures and contextualized within the country's process of democratization. This discourse must be observed as context dependent, since pessimistic views on reality have been expressed in line with overall disappointment with the country's late transition to democracy. Restrained freedoms of the past are contrasted to 'the golden age of journalism', but students do not differentiate between various periods. It is not clear whether the best and the worst of times are interpreted within the same time frame or not, because the past is addressed in a more abstract way. The 'cognitive distance' from the past, wherever it has been referred to, has strongly influenced the students' views of the present state of journalism. This leads to the argument that the future is a continuation of existing restrictions rather than a potential place for improvement. Even the final call for the ultimate battle against profit-oriented, uncompetitive, politically influenced journalism does not provide solutions to the detected problems, but rather, mere descriptions of what is desired.

Professional dynamics was described as a carousel where poor economic and social status, lack of professional and ethical standards and inner-newsroom pressures spin around the foundations of journalism. Reshaping the power of the profession is expected to be in the hands of educated professionals, even though other social groups are acknowledged as contributors to the openness of the profession. This perspective of the students clearly demarcated their need to strongly participate in the rise 
The Future of Journalism as a System, Profession and Culture: The Perception...

of the fallen profession, while at the same time diminished the role of the audience in reshaping its core. Similar to the previously discussed section, the changes in this aspect are anticipated more in terms of general observations rather than concrete suggestions for professional progress.

The analyzed narratives mostly address the institutional roles of journalism from an outsiders' perspective, since students are still only observers of or sporadic participants in the professional culture. Therefore, the dominant discourse is related to the entertaining role and various aspects of news sensationalism, which correspond to market orientation as the third dimension of institutional roles, according to Hanitzsch (2007). Pessimistic views about the future are connected with blurred lines between the informative and entertaining roles of journalism. Negative perceptions of citizen journalism and other aspects of audience engagement in news production are rooted in their impressions of the audience as supporters of lower quality, tabloid, sensational journalism rather than contributors who are able to improve the media content. These 'elitist' views strongly correlate to students' perceptions of the profession, which they believe should be reshaped only by educated journalists. This exclusion of 'the others' in contemplations of the future derives from students' disappointment of the celebritization of the news, popular reality programs and easy entertaining content. The ideals recognized in the settings of 'old' democracies of the West are seen as the cornerstone of the future of journalism in Serbia. That is, journalists are seen as becoming more independent from various kinds of pressures in a more pragmatic environment, where the gate-keeping, informative and interpretive roles are seen as prerogatives.

\section{Conclusion}

Content analysis of the students' essays, based on the three theoretical understandings of journalism, has shown a high correlation between academic and student contemplations about journalism. References to journalism as a culture, profession and societal system were almost equally present in the students' narratives. Furthermore, qualitative content analysis of the essays has revealed almost all lines of scholarly thinking presented in the theoretical overview. The students have addressed journalism as a system in relation to democratic values and discussed the autonomy of journalism from economic and political sub-systems. Further, the students have referred to journalism as a profession and have raised the issue of education as a precondition for entering the profession, the low economic and social status of journalists, upholding professional and ethical standards, and professional integrity and autonomy. Three distinctive themes regarding students' perceptions of journalism as a culture were identified: the entertaining role; informative, gatekeeping and watchdog role; and interpretative role. 
These results might correspond with arguments about the globalization of journalism education (Deuze, 2006), journalism ethics (Ward, 2005), consolidation of occupational ideology (Deuze, 2008), or even news (Leuven \& Berglez, 2015), which are coherent with the outlined trend of consolidating journalism studies. However, another interpretation is also possible. The findings in this research could be in alignment with calls for de-westernizing media studies and journalism (Curran \& Park, 2000; Josephi, 2005) and rising awareness about the dominance of the AngloAmerican model of teaching and practicing journalism. This perspective can be amplified by the well-known discrepancy between the principles of journalism and professional practice within the context of the Serbian media system. Although the crisis of journalism can be considered to be global (McChesney, 2003; Russial et al., 2015), its local shape clearly emerges from the students' narratives. The students have outlined almost all the challenges that journalism in Serbia faces, and demonstrated an excellent understanding of the national media landscape. Starting from normative predispositions of journalism, they have been highly critical about the way journalism functions in Serbia. However, their contestations were not coupled with a proper comprehension of the trajectories of media democratization. Namely, recent overviews of the transitional process in the CEE have highlighted the shortcomings of moulding rather diversified post-communist settings according to the same western model (Jakubowicz \& Sükösd, 2008). Serbian journalism students have evaluated the current trends as departing from the same postulates, and have neglected the complex layers of different historical periods.

This analysis has also shown how students' perceptions about the future of journalism have been significantly shaped both by the Serbian media landscape and the UB FPS journalism curricula. On the one hand, they are well aware of the shortcomings of the current state of journalism in the country and show some commitment to act as agents of change in the future. On the other hand, their contemplations have been rather influenced by the faculty's journalism curricula and, moreover, by personal views of the professors they have quoted throughout the essays. We noticed that students, even when writing about their own perceptions, sometimes cited the views of their professors heard during the journalism courses and therefore built the essays around those thoughts. This influence was revealed in the students' idealized views on quality journalism, which they insisted should employ only highly educated professionals, or through their labelling of the tabloids and tabloid journalists as 'diggers of social garbage' that they would not want to become. More broadly, as this analysis has shown, the students' views were more descriptive than analytical, mostly mirroring the current Serbian media landscape and lessons learnt during the previous years of studies.

Based on these results, it is recommended that journalism educators in Serbia implement more courses on media and journalism history in Serbia, while more broadly, 
The Future of Journalism as a System, Profession and Culture: The Perception...

scholars could ask themselves whether they foster pure 'reproduction' of knowledge and nurture conformist attitudes, or support the development of 'independent thinkers'. Overall, this article stresses that students' voices should be included more in discussions on the legacy of journalism, its performance and multilayered manifestations. Although the analysis relied on the perceptions of Belgrade University students, we have tried to move forward from the national boundaries and to provide an interpretation of the contemporary global developments, malfunctions and challenges that journalism has been facing. Therefore, the presented results may serve as a solid basis for further studies in this field and may be enriched by national, regional or global comparisons.

\section{REFERENCES}

Abbott, A. D. (1988) The System of Professions: An Essay on the Division of Expert Labor. Chicago: University of Chicago Press.

Anderson, C. (2008) "Journalism: expertise, authority, and power in democratic life”, pp. 248-264. In: Hesmondhalgh D. \& Toynbee J. (Eds.): The Media and Social Theory. New York. Routledge.

Bagdikian, B. (2004) The New Media Monopoly. Boston: Beacon Press.

Baker, P., Gabrielatos, C., Khosravinik, M., Krzyżanowski, M., McEnery, T., \& Wodak, R. (2008). "A useful methodological synergy? Combining critical discourse analysis and corpus linguistics to examine discourses of refugees and asylum seekers in the UK press", Discourse \& Society, 19 (3), 273-306.

Van Leuven, S., \& Berglez, P. (2015) “Global journalism between dream and reality: A comparative study of The Times, Le Monde and De Standaard", Journalism Studies, 1 (17), 667-683.

Blaagaard, B. B. (2013) "Shifting boundaries: Objectivity, citizen journalism and tomorrow's journalists", Journalism, 14 (8), 1076-1090.

Brannen, J. (2005) "Mixing methods: The entry of qualitative and quantitative approaches into the research process", International Journal of Social Research Methodology, 8(3), 173-184.

Bryman, A. (2004) Social Research Methods (2nd ed.). New York: Oxford University Press.

Curran, J., \& Park, M. J. (2000) De-Westernizing Media Studies. London: Routledge.

Dahlgren, P. (2009) Media and Political Engagement. New York: Cambridge University Press.

Das, J. (2007) "Sydney freelance journalists and the notion of professionalism", Pacific Journalism Review, 13 (1), 142-160. 
Medij. istraž. (god. 22, br. 2) 2016. (83-105)

Deuze, M. (2004) "Journalism studies beyond media: On ideology and identity", Ecquid Novi: African Journalism Studies, 25 (2), 275-293.

Deuze, M. (2005). "What is journalism? Professional identity and ideology of journalists reconsidered", Journalism, 6 (4), 442-464.

Deuze, M. (2006) "Global journalism education”, Ecquid Novi: African Journalism Studies, 23 (1), 89-93.

Deuze, M., (2008) Understanding journalism as newswork. Westminster Papers in Communication and Culture, 5 (2), 4-24.

Domingo, D. (2008) “Inventing online journalism”, pp. 15-28. In: Paterson, C. \& Domingo, D. (Eds.): Making Online News: The Ethnography of New Media Production. New York. Peter Lang

Evetts, J. (2003) "The sociological analysis of professionalism: Occupational change in the modern world", International Sociology, 18 (2), 395-415.

Fengler, S. \& Ruß-Mohl, S. (2008) "Journalists and the information-attention markets: Towards an economic theory of journalism", Journalism, 9 (6), 667-690.

Görke, A. \& Scholl, A. (2006) "Nikolas Luhmann's theory of social systems and journalism research", Journalism Studies, 7 (4), 644-655.

Hallin, D. C. \& Mancini, P. (2004) Comparing Media Systems: Three Models of Media and Politics. New York: Cambridge University Press.

Hanitzsch, T. (2007) "Deconstructing journalism culture: Toward a universal theory", Communication Theory, 17 (4), 367-385.

Hanitzsch, T. et al. (2011) "Mapping journalism cultures across nations", Journalism Studies, 12 (3), 273-293.

Hartley, J. (1999) "What is journalism? The view from under a stubbie cap", Media International Australia incorporating Culture and Policy, 90 (1), 15-33.

IREX (2013) Media Sustainability Index: Serbia, http://www.irex.org/project/media-sustainability-index-msi.

Josephi, B. (2005) "Journalism in the global age between normative and empirical", International Communication Gazette, 67 (6), 575-590.

Jakubowicz, K., \& Sükösd, M. (Eds.) (2008) Finding the Right Place on the Map: Central and Eastern European Media Change in a Global Perspective. Bristol: Intellect Books.

Koljonen, K. (2013) "The shift from high to liquid ideals", Nordicom Review, 34 (Special Issue), 141-154.

Krippendorff, K. (2004) Content analysis: An Introduction to Its Methodology. London: Sage.

Krstić, A. (2012) "Novinarstvo i medijska industrija u Srbiji - profesionalni dobitak, ekonomski gubitak", CM - časopis za upravljanje komuniciranjem, 7 (24), 115-132. 
The Future of Journalism as a System, Profession and Culture: The Perception...

Krstić, A. (2016) "Local Television As a Business: Comparative Perspectives Of Commercial Television Stations In Serbia”, Teme - časopis za društvene nauke, 40 (1), 229-244.

Larson, M. S. (1977) The Rise of Professionalism a Sociological Analysis. Los Angeles: University of California.

Löffelholz, M. \& Quandt, T. (2005) "Journalism theory: Developments in German speaking countries", Ecquid Novi: African Journalism Studies, 26 (2), 228-246.

Loosen, W. (2015) “The notion of the "blurring boundaries", Digital Journalism, 3 (1), 68-84.

Luhmann, N. (1996) Die Realität der Massenmedien. Weisbaden: VS Verlag für Sozialwissenschaften.

Mancini, P. (2012) "Instrumentalization of the media vs. political parallelism", Chinese Journal of Communication, 5 (3), 262-280.

McChesney, R. W. (2003) "The problem of journalism: A political economic contribution to an explanation of the crisis in contemporary US journalism", Journalism Studies, 4 (3), 299-329.

McManus, J. H. (1994) Market-Driven Journalism. Los Angeles: Sage.

McNair, B. (2003) Sociology of Journalism. London: Routledge.

McNair, B. (2005) "What is journalism?" pp. 25-44. In: De Burgh, H. (Ed.): Making Journalists: Diverse Models, Global Issues. New York. Routledge.

Mellado, Claudia et al. (2013) "The pre-socialization of future journalists", Journalism Studies, 14 (6), 857-874.

Merrill, John C. \& Nerone, John C. (2002) "The four theories of the press four and a half decades later: A retrospective", Journalism Studies, 3 (1), 133-136.

Milivojević, S., Radojković, M., Milojević, A., Ugrinić, A., Krstić, A., \& Matović, M. (2012) Profesija na raskršću - novinarstvo na pragu informacionog društva. Beograd: Centar za medije i medijska istraživanja, Fakultet političkih nauka.

Nerone, J. (2013) "The historical roots of the normative model of journalism", Journalism, 14 (4), 446-458.

Nygren, G., Degtereva, E. \& Pavlikova, M. (2010) “Tomorrow's journalists: Trends in the development of the journalistic profession as seen by Swedish and Russian students", Nordicom Review, 31 (2), 113-133.

Onwuegbuzie, A. J., Johnson, R. B., \& Collins, K. M. (2009) "Call for mixed analysis: A philosophical framework for combining qualitative and quantitative approaches". International Journal of Multiple Research Approaches, 3 (2), 114-139.

Örnebring, H. (2009) The Two Professionalisms of Journalism: Updating Journalism Research for the 21st Century - Working Paper. Oxford: Reuters Institute for the Study of Journalism, Oxford University. 
Medij. istraž. (god. 22, br. 2) 2016. (83-105)

Örnebring, H. (2013) “Anything you can do, I can do better? Professional journalists on citizen journalism in six European countries", International Communication Gazette, 75 (1), 35-53.

Paterson, C. A. \& Domingo, D. (Eds.) (2008) Making Online News: The Ethnography of New Media Production. New York: Peter Lang.

Russial, J., Laufer, P. \& Wasko, J. (2015) “Journalism in crisis?”, Javnost-The Public, 22 (4), 299-312.

Schudson, M. \& Anderson, C. (2008) "Objectivity, professionalism, and truth seeking in journalism”, pp. 88-101. In: Wahl-Jorgensen K. \& Hanitzsch T. (Eds.): Handbook of Journalism Studies. New York. Routledge.

Schudson, M. (2003) Sociology of News. New York: W.W. Norton.

Soloski, J. (1989) "News reporting and professionalism: Some constraints on the reporting of the news", Media, Culture \& Society, 11 (2), 207-228.

Steensen, S., \& Ahva, L. (2015) "Theories of journalism in a digital age: An exploration and introduction", Journalism Practice, 9 (1), 1-18.

Štětka, V. (2013) "Media Ownership and Commercial Pressures", Media and Democracy in Central and Eastern Europe. ERC funded project, Pillar 1 - Final report, The London School of Economics and Political Science. Retrieved from http://mde.politics.ox.ac.uk/

Tuchman, G. (1978) Making News. A Study in the Construction of Reality. New York: The Free Press.

Van Dijk, T. A. (1993) "Principles of critical discourse analysis", Discourse \& Society, 4 (2), 249-283.

Vobič, I. (2014) "Three paradigms of journalistic objectivity in Slovenian press history", Central European Journal of Communication, 1 (12), 4-17.

Wahl-Jorgensen, K., \& Hanitzsch, T. (2009) "Introduction: On why and how we should do journalism studies”, pp. 3-16. In: Wahl-Jorgensen, K. \& Hanitzsch, T. (Eds.): The Handbook of Journalism Studies. New York. Routledge.

Ward, S. J. (2005) "Philosophical foundations for global journalism ethics", Journal of Mass Media Ethics, 20 (1), 3-21.

Weischenberg, S., Malik, M. \& Scholl, A. (2012) "Journalism in Germany in the 21st century”, pp. 205-219. In: Weaver, D. H. \& Willnat, L. (Eds.): The Global Journalist in the 21st Century. New York. Routledge.

Zelizer, B. (1992) Covering the Body. Chicago: University of Chicago Press.

Zelizer, B. (2004) Taking Journalism Seriously: News and the Academy. Thousand Oaks, CA: Sage. 


\title{
Budućnost novinarstva kao sustava, profesije i kulture kako to vide studenti novinarstva
}

\author{
Ana Milojević \\ Aleksandra Krstić \\ Aleksandra Ugrinić
}

\section{SAŽETAK}

U posljednje vrijeme postoji jaka potreba da se tradicionalno novinarstvo redefinira. Namjera ovog rada jest uključiti glasove budućih novinara u tu debatu. Stoga je studentima novinarstva Sveučilišta u Beogradu zadano pisanje eseja o budućnosti novinarstva. Radi sistematiziranja njihovih pripovijesti, tri teorijska shvaćanja novinarstva uvode se na temelju pregleda literature: novinarstvo kao društveni sustav, profesija i kultura. Eseji su ispitani pomoću kvantitativne i kvalitativne analize sadržaja i kritičke analize diskursa. U radu se raspravljaju studentska predviđanja promjena u novinarstvu kao sustavu, zanimanju i kulturi, s posebnom pozornošću prema korištenom leksiku kako bi se dekonstruirao način na koji studenti procjenjuju budućnost novinarstva. Nadalje, rad pokazuje također i kako studenti percipiraju svoju ulogu u redefiniranju novinarstva.

Ključne riječi: studije novinarstva, novinarstvo, studenti, kritička analiza diskursa, budućnost novinarstva 